\title{
FORMULASI DAN UJI EFEKTIVITAS ANTIBAKTERI SEDIAAN GEL EKSTRAK ETANOL DAUN KERSEN (Muntingia calabura L.) SEBAGAI ANTISEPTIK TANGAN
}

\author{
Thesya Manarisip ${ }^{1)}$, Paulina V.Y Yamlean ${ }^{1)}$, Widya Astuty Lolo ${ }^{1)}$ \\ ${ }^{1)}$ Program Studi Farmasi FMIPA UNSRAT Manado, 95115
}

\begin{abstract}
Kerson Fruit (Muntingia calabura L.) contains bioactive compounds, such as flavonoids, saponins, triterpenes, steroids, and tannins, which are potentially as antibacterial compounds. The aim of this study was to make a formulation of hand antiseptic gel from kerson leaf extracts with three variations in extract concentrations of 5\%,10\%, and 15\%, and to test the effectiveness of antibacterial preparations against Staphylococcus aureus bacteria. The method of this research is laboratory experimental research. Kerson extracts was obtained by maceration using $96 \%$ ethanol. The results showed that kerson leaf extract can be formulated as a hand antiseptic gel preparation that meets organoleptic requirements, like homogeneity, $\mathrm{pH}$, dispersion, consistency, adhesion, cycling test, and antiseptic power testing using a colony counter. On the results of antibacterial effectiveness testing, there is a clear zone that presents the ability to inhibit the growth of gel test bacteria. The average diameter of the hand antiseptic gel preparation of kersen leaf extract at concentrations of 5\%,10\%, and $15 \%$ respectively were $10.00 \mathrm{~mm}, 11.66 \mathrm{~mm}$ and $12.00 \mathrm{~mm}$ so that the ability of inhibition of gel test bacteria in all concentrations was categorized strong.
\end{abstract}

Keywords: Kerson, Muntingia calabura L, Hand Antiseptic Gel, Staphylococcus aureus.

\begin{abstract}
ABSTRAK
Kersen (Muntigia calabura L.) mengandung senyawa bioaktif yaitu senyawa flavonoid, saponin, triterpen, steroid, dan tannin yang merupakan senyawa yang berpotensi sebagai antibakteri. Penelitian ini bertujuan untuk membuat formulasi sediaan gel antiseptik tangan dari ekstrak daun kersen dengan tiga variasi konsentrasi ekstrak yakni $5 \%, 10 \%$, dan $15 \%$, serta menguji efektivitas antibakteri sediaan terhadap bakteri Staphylococcus aureus. Metode penelitian ini merupakan penelitian eksperimental laboratorium. Ekstrak tanaman kersen diperoleh dengan cara maserasi menggunakan pelarut etanol 96\%. Hasil penelitian menunjukkan bahwa ekstrak daun kersen dapat diformulasikan sebagai sediaan gel antiseptik tangan yang memenuhi persyaratan organoleptik, homogenitas, $\mathrm{pH}$, daya sebar, konsistensi, daya lekat, cycling test, dan pengujian daya antiseptik dengan menggunakan alat colony counter. Pada hasil pengujian efektivitas antibakteri, terdapat zona bening yang mempresentasikan kemampuan penghambatan pertumbuhan bakteri uji oleh gel. Diameter rata-rata sediaan gel antiseptik tangan ekstrak daun kersen pada konsentrasi 5\%, 10\%, dan $15 \%$ berturut-turut yaitu $10,00 \mathrm{~mm}, 11,66 \mathrm{~mm}$ dan 12,00 mm sehingga kemampuan penghambatan bakteri uji oleh gel disemua konsentrasi dikategorikan kuat.
\end{abstract}

Kata kunci: Kersen, Muntingia calabura L, Gel Antiseptik Tangan, Staphylococcus aureus. 
PHARMACON- PROGRAM STUDI FARMASI, FMIPA, UNIVERSITAS SAM RATULANGI,

Volume 8 Nomor 3 Agustus 2019

PENDAHULUAN

Infeksi adalah penyakit yang disebabkan oleh mikroba patogen dan bersifat sangat dinamis. Mikroba sebagai mahluk hidup tentunya ingin bertahan hidup dengan cara berkembang biak pada suatu reservoir baru dengan cara berpindah atau menyebar. Mekanisme transmisi mikroba patogen ke pejamu yang rentan dapat melalui cara tidak langsung seperti menyentuh barang/bahan yang terkontaminasi, mengonsumsi makanan atau minuman yang terkontaminasi. Manusia dalam kehidupan sehari-hari akan menyentuh suatu permukaan, baik itu permukaan tubuh, benda, ataupun bahan, sehingga tangan akan mengandung banyak mikroorganisme, oleh karena itu dapat dikatakan bahwa tangan merupakan salah satu faktor penting dalam jalur penyebaran bakteri dan virus yang dapat menyebabkan penyakit (Retno, 2005). Salah satu bentuk penyebaran mikroorganisme pada manusia adalah melalui tangan. Tangan merupakan alat transmisi dari mikroorganisme pada saluran pernafasan dan mulut yang utama (Lindawati et al, 2008).

Diare merupakan salah satu penyakit akibat dari infeksi bakteri patogen yang memiliki angka morbiditas dan mortalitas tertinggi di dunia. Hasil Riset Kesehatan Dasar (Riskesdas) pada tahun 2013 menunjukkan terjadinya penurunan prevalensi diare klinis di Indonesia dari 9,0\% pada tahun 2007 menjadi 3,5\% pada tahun 2013. Penurunan angka diare ini berbanding lurus dengan meningkatnya angka kehigienisan tangan di masyarakat yang mengacu pada data Riskesdas pada tahun 2013 yang menyatakan bahwa perilaku mencuci tangan dengan benar di Indonesia meningkat dari 23,2\% pada tahun 2007 menjadi 47,0\%, sehingga perilaku mencuci tangan berperan penting dalam penurunan penyakit diare (Anonim, 2013).
Membersihkan tangan dengan bahan antiseptik mulai dikenal sejak awal abad 19. Antiseptik merupakan zat yang digunakan untuk menghambat pertumbuhan atau membunuh mikroorganisme yang hidup di permukaan tubuh. Mekanisme kerja antiseptik ini antara lain merusak lemak pada membran sel bakteri atau dengan cara menghambat salah satu kerja enzim pada bakteri yang berperan dalam biosintesis asam lemak (Retno, 2005).

Salah satu bahan alam yang memiliki potensi untuk dikembangkan sebagai antiseptik tangan ialah Kersen (Muntingia calabura L). Berdasarkan hasil penelitian daun kersen mengandung berbagai senyawa bioaktif yaitu senyawa flavonoid, saponin, triterpen, steroid, dan tannin. Dimana senyawa bioaktif ini merupakan senyawa yang berpotensi sebagai antibakteri (Kuntorini, 2011).

Berdasarkan latar belakang tersebut maka peneliti tertarik untuk melakukan penelitian tentang formulasi dan uji efektivitas antibakteri gel ekstrak Daun Kersen sebagai antiseptik tangan. Gel antiseptik tangan merupakan sediaan yang berbentuk gel yang digunakan untuk mengurangi atau menghambat pertumbuhan mikroorganisme tanpa membutuhkan air. Cara pemakaian gel antiseptik ialah dengan meneteskan gel pada telapak tangan, kemudian diratakan pada permukaan tangan (Girou et al, 2002).

\section{METODOLOGI PENELITIAN Bentuk Penelitian}

Penelitian yang dilakukan bersifat eksperimental laboratorium yang membuat formula dan uji efektivitas gel ekstrak daun Kersen sebagai antiseptik tangan. 


\section{Waktu dan Tempat Penelitian}

Penelitian ini dilaksanakan pada bulan November 2018 - Juni 2019 di Laboratorium Penelitian Farmasi Lanjut Program Studi Farmasi dan Laboratorium Biologi Dasar Fakultas Matematika dan Ilmu Pengetahuan Alam Universitas Sam Ratulangi Manado.

\section{Alat dan Bahan}

a. Alat

Alat yang digunakan pada penelitian ini ialah batang pengaduk, blender (Waring Commercial), erlenmeyer $300 \mathrm{~mL}$ (pyrex), gelas ukur $100 \mathrm{~mL}$ (pyrex), gelas piala 500 $\mathrm{mL}$ (pyrex), kaca preparat, tabung reaksi (pyrex), cawan petri (pyrex), corong pisah (pyrex), penggaris, gunting, pot gel, timbangan digital (aeDAM®), sarung tangan dan masker, kertas saring, kamera (Samsung), hot plate (ACIS), colony counter (Stuart Scientific), laminar air flow (LAF) (NBioteck), magnetic stirrer, aluminum foil, lemari pendingin, pipet tetes, mikropipet (ecopipette $^{\mathrm{TM}}$ ), mortar dan sudip, ayakan mesh 200, pH stik universal (MERCK), kapas dan kertas label, autoklaf (ALP), cawan porselin, inkubator (MMM Gramoup), centrifugal (Gemmy Industrial Corp).

\section{b. Bahan}

Bahan yang digunakan dalam penelitian ini ialah daun kersen, etanol 96\%, aquades, gliserin, $\mathrm{CMC}-\mathrm{Na}$, propilenglikol, handsanitizer Carex ${ }^{\circledR}$, nutrient agar (NA) dan bakteri Staphylococcus aureus.

\section{Prosedur Penelitian}

\section{Ekstraksi}

Pembuatan ekstrak dilakukan dengan metode maserasi yaitu sebanyak 400 gram serbuk simplisia daun kersen dimasukkan ke dalam gelas beker lalu direndam dalam pelarut etanol $96 \%$ sebanyak $1600 \mathrm{ml}$ dengan perbandingan 1:4, kemudian wadah ditutup dengan aluminium foil dan dibiarkan selama 4 hari sambil sesekali diaduk, lalu disaring dengan kertas saring sehingga menghasilkan filtrat dan residu. Residu yang ada kemudian direndam lagi (remaserasi) dengan etanol 96\% sebanyak $1200 \mathrm{ml}$, selanjutnya wadah ditutup dengan aluminium foil dan dibiarkan selama 2 hari sambil sesekali diaduk. Setelah 2 hari, sampel disaring sehingga menghasilkan filtrat dan residu. Filtrat satu dan filtrat dua dicampurkan menjadi satu lalu diuapkan dengan menggunakan oven pada suhu $40^{\circ} \mathrm{C}$ selama 2 hari, sehingga diperoleh ekstrak kental. Ekstrak kental yang telah dihasilkan ditimbang dan disimpan dalam wadah gelas tertutup sebelum digunakan untuk pengujian.

\section{Formulasi dan Pembuatan Krim}

Pada penelitian ini akan dibuat sediaan gel antiseptik tangan dengan tiga variasi konsentrasi, yaitu $5 \%, 10 \%$, dan $15 \%$ pada daun kersen yang dipakai. Menurut Maswadeh et al., (2006) Formulasi standar basis gel CMC ialah sebagai berikut:

Tabel 1.Formulasi Gel Ekstrak Etanol Daun Kersen 5\%,10\%,15\%

\begin{tabular}{cccc}
\hline Komponen & Konsentrasi & Konsentrasi & Konsentrasi \\
& $5 \%$ & $10 \%$ & $15 \%$ \\
\hline Ekstrak daun Kersen & $2,5 \mathrm{~g}$ & $5 \mathrm{~g}$ & $7,5 \mathrm{~g}$ \\
CMC-Na & $2,5 \mathrm{~g}$ & $2,5 \mathrm{~g}$ & $2,5 \mathrm{~g}$ \\
Gliserin & $5 \mathrm{ml}$ & $5 \mathrm{ml}$ & $5 \mathrm{ml}$ \\
Propilenglikol & $0,5 \mathrm{ml}$ & $0,5 \mathrm{ml}$ & $0,5 \mathrm{ml}$ \\
Aquades ad & 50 & 50 & 50 \\
\hline
\end{tabular}




\section{Pembuatan Krim}

Cara pembuatan formulasi gel ialah disiapkan semua bahan yang akan digunakan. Bahan ditimbang terlebih dahulu sesuai dengan formulasi. Ekstrak dengan konsentrasi $5 \%$ dilarutkan dalam sebagian air yang telah dipanaskan pada suhu $50^{\circ} \mathrm{C}$. Ditambahkan CMC-Na dan diaduk sampai homogen. Ditambahkan gliserin, propilenglikol dan air dengan pengadukan secara kontinyu hingga terbentuk gel. Gel yang telah terbentuk kemudian disimpan pada suhu ruangan selama semalam (Hamzah, 2006). Prosedur yang sama juga dilakukan pada ekstrak dengan konsentrasi $10 \%$ dan $15 \%$.

\section{Evaluasi sediaan Krim Ekstrak daun Beluntas}

Pengujian stabilitas sediaan gel ekstrak daun Kersen menggunakan beberapa jenis pengujian yang merupakan persyaratan kelayakan sediaan gel diantaranya adalah :

a. Uji Organoleptik

Pemeriksaan ini bertujuan untuk mengamati ada tidaknya perubahan bentuk, warna dan bau. Gel yang baik adalah Gel yang memiliki ciri organoleptik warna putih, tidak berubah warna, basis dan bau dalam penyimpanan (Ansel, 1989).

b. Uji Homogenitas

Pengujian Homogenitas dilakukan dengan cara sampel gel dioleskan pada sekeping kaca atau bahan transparan lain yang cocok, sediaan harus menunjukkan susunan yang homogen dan tidak terlihat adanya butiran kasar (Kumesan et al, 2013).

c. Uji pH

Penentuan $\mathrm{pH}$ sediaan dilakukan dengan menggunakan stik $\mathrm{pH}$ universal yang dicelupkan ke dalam sampel gel yang telah diencerkan. Setelah tercelup dengan sempurna, $\mathrm{pH}$ universal tersebut dilihat perubahan warnanya dan dicocokkan dengan standar $\mathrm{pH}$ universal, $\mathrm{pH}$ sediaan gel harus sesuai dengan $\mathrm{pH}$ kulit yaitu 4,5-6,5 (Tranggono et al, 2007).

d. Uji Daya Sebar

Sebanyak $1 \mathrm{~g}$ sampel gel diletakkan diatas kaca bulat berdiameter $15 \mathrm{~cm}$, kaca lainnya diletakkan di atasnya dan dibiarkan selama 1 menit. Diameter sebar gel diukur. Setelahnya ditambahkan 200 gr beban tambahan dan didiamkan selama 1 menit lalu diukur diameter yang konstan. Menurut Garg et al (2002), daya sebar 5-7 cm menunjukkan konsistensi semisolid yang sangat nyaman dalam penggunaan.

e. Uji Konsistensi

Dilakukan dengan mengamati perubahan konsistensi dari sediaan gel yang dibuat apakah terjadi pemisahan antara bahan pembentuk gel dengan pembawanya yaitu air. Pengujian konsistensi menggunakan pengujian centrifugal test dimana sampel gel disentrifugasi pada kecepatan $3800 \mathrm{rpm}$ selama 5 jam kemudian diamati perubahan fisiknya (Djajadisastra, 2009).

f. Uji Daya Lekat

Uji daya lekat dilakukan dengan cara 0.5 gram gel diletakkan dibagian tengah gelas objek dan ditutup dengan gelas objek lain, kemudian ditekan dengan beban $1 \mathrm{~kg}$ diatasnya selama 5 menit, gelas objek tersebut dipasang pada alat uji yang diberi beban 80 gram. Dihitung waktu yang diperlukan dua gelas objek hingga terlepas (Swastika et al, 2013).

\section{g. Cycling Test}

Salah satu cara mempercepat evaluasi kestabilan fisik adalah dengan metode dengan cycling test ini dilakukan sebanyak 6 siklus. Sediaan krim disimpan pada suhu dingin \pm $4^{0} \mathrm{C}$ selama 12 jam lalu dikeluarkan dan ditempatkan pada suhu $\pm 40^{\circ} \mathrm{C}$. proses ini dihitung 1 siklus. Kondisi fisik krim dibandingkan selama percobaan dengan sediaan sebelumnya (Dewi, 2010). 
Pengujian Aktivitas Antibakteri

Uji aktivitas antibakteri terhadap gel ekstrak Etanol daun Kersen menggunakan bakteri Staphylococcus aureus dengan cara difusi agar. 3 sumuran untuk setiap konsentrasi gel ekstrak Etanol daun Kersen $5 \%, 10 \%$ dan $15 \%$ dan dua sumuran lain untuk kontrol positif (gel antiseptik tangan) dan kontrol negatif (basis gel)

HASIL DAN PEMBAHASAN

Tabel 2. Hasil Uji Organoleptik Gel Ekstrak Etanol Daun Kersen

\begin{tabular}{lllclll}
\hline \multicolumn{3}{c}{ Sebelum Penyimpanan } & \multicolumn{3}{c}{ Setelah Penyimpanan } \\
\hline Krim & Bau & Warna & Bentuk & Bau & Warna & Bentuk \\
\hline FI & Khas & Cokelat & Semi padat & Khas & Cokelat & Semi padat \\
& Ekstrak & & & Ekstrak & & \\
\multirow{2}{*}{ FII } & Khas & Cokelat & Semi padat & Khas & Cokelat tua & Semi padat \\
& Ekstrak & & & Ekstrak & & \\
\multirow{2}{*}{ FII } & Khas & Cokelat & Semi padat & Khas & Cokelat gelap & Semi padat \\
& Ekstrak & gelap & & Ekstrak & & \\
\hline
\end{tabular}

Tabel 3. Hasil Uji Homogenitas Gel Ekstrak Daun Kersen

\begin{tabular}{lcc}
\hline & Sebelum Penyimpanan & Setelah Penyimpanan \\
\hline Krim & Homogenitas & Homognenitas \\
\hline FI & Homogen & Homogen \\
FII & Homogen & Homogen \\
FII & Homogen & Homogen \\
\hline
\end{tabular}

Tabel 4. Hasil Uji pH Gel Ekstrak Etanol Daun Kersen

\begin{tabular}{lcc}
\hline & Sebelum Penyimpanan & Setelah Penyimpanan \\
\hline Krim & Ph & pH \\
\hline FI & 5,74 & 5,68 \\
FII & 5,77 & 5,54 \\
FIII & 5,56 & 5,48 \\
\hline
\end{tabular}

Tabel 5. Hasil Uji Daya Sebar Gel Ekstrak Etanol Daun Kersen

\begin{tabular}{lcc}
\hline & Sebelum Penyimpanan & Setelah Penyimpanan \\
\hline Krim & Diameter Sebar Gel & Diameter Sebar Gel \\
\hline FI & $5,7 \mathrm{~cm}$ & $5,5 \mathrm{~cm}$ \\
FII & $6,0 \mathrm{~cm}$ & $5,7 \mathrm{~cm}$ \\
FIII & $6.2 \mathrm{~cm}$ & $5,9 \mathrm{~cm}$ \\
\hline
\end{tabular}


Tabel 6. Hasil Uji Daya Lekat Gel Ekstrak Etanol Daun Kersen

\begin{tabular}{llc}
\hline & Sebelum Penyimpanan & Setelah Penyimpanan \\
\hline Krim & Waktu & Waktu \\
\hline FI & 6,00 detik & 10,00 detik \\
FII & 6,20 detik & 11,73 detik \\
FIII & 12,62 detik & 12,53 detik \\
\hline
\end{tabular}

Tabel 7. Pengujian Konsistensi Gel Ekstrak Etanol Daun Kersen

\begin{tabular}{lcc}
\hline & Sebelum Penyimpanan & Setelah Penyimpanan \\
\hline Krim & Konsistensi & Konsistensi \\
\hline FI & Tidak terjadi pemisahan fase & Tidak terjadi pemisahan fase \\
FII & Tidak terjadi pemisahan fase & Tidak terjadi pemisahan fase \\
FIII & Tidak terjadi pemisahan fase & Tidak terjadi pemisahan fase \\
\hline
\end{tabular}

Tabel 8. Hasil Pegujian Mikrobiologi Gel Ekstrak Etanol Daun Kersen

\begin{tabular}{lcccc}
\hline Formulasi & \multicolumn{4}{c}{ Diameter daerah hambatan (mm) } \\
& Ulangan I & Ulangan & Ulangan & Rata-rata \\
& I & II & III & \\
\hline K (-) & 0 & 0 & 0 & 0 \\
K (+) & 15,00 & 15,00 & 15,00 & 15,00 \\
FI & 9,00 & 11,00 & 10,00 & 10,00 \\
FII & 11,00 & 12,00 & 12,00 & 11,66 \\
FIII & 11,00 & 12,00 & 13,00 & 12,00
\end{tabular}

Tabel 9. Hasil Pengujian Antiseptik Gel Ekstrak Etanol Daun Kersen

\begin{tabular}{c|c}
\hline Formulasi & Jumlah Koloni Bakteri \\
\hline K (-) & 27 \\
K (+) & 15 \\
F1 & 20 \\
F2 & 14 \\
F3 & 11 \\
\hline
\end{tabular}

\section{PEMBAHASAN}

Penelitian ini dilakukan dengan memformulasikan sediaan gel antiseptik tangan dengan menggunakan ekstrak daun dari Tanaman Kersen. Tanaman kersen mengandung berbagai senyawa bioaktif yaitu senyawa flavonoid, saponin, triterpen, steroid, dan tanin. Dimana senyawa bioaktif ini merupakan senyawa yang berpotensi sebagai antibakteri yang berpotensi untuk diformulasi 
PHARMACON- PROGRAM STUDI FARMASI, FMIPA, UNIVERSITAS SAM RATULANGI,

Volume 8 Nomor 3 Agustus 2019

menjadi sediaan gel antiseptik yang dapat menghambat dan membunuh bakteri pada telapak tangan (Kuntorini, 2011).

Simplisia yang diperoleh diblender kemudian diayak menggunakan ayakan untuk mendapatkan serbuk yang halus dan seragam. Serbuk simplisia yang diperoleh sebanyak 400 gram. Proses penghalusan simplisia menjadi serbuk dilakukan agar supaya proses penarikan senyawa aktif yang terkandung dalam simplisia semakin optimal itu di karenakan luas permukaan dari simplisia yang bersentuhan dengan pelarut semakin meningkat. Ekstraksi terhadap serbuk simplisia daun Kersen dilakukan dengan menggunakan ekstraksi cara dingin, yaitu metode maserasi. Maserasi merupakan proses penyarian senyawa kimia secara sederhana dengan merendam simplisia atau tumbuhan pada suhu kamar dengan menggunakan pelarut yang sesuai sehingga bahan menjadi lunak dan larut. Proses ekstraksi dilakukan dengan menggunakan pelarut Etanol 96\% karena pelarut ini menyari hampir keseluruhan kandungan simplisia baik non polar,semi polar maupun polar (Iswanti, 2009). Pelarut ini bersifat selektif, tidak beracun dan bersifat universal yang cocok untuk mengekstrak semua golongan senyawa metabolit sekunder (Kristanti et al, 2008). Proses maserasi dilakukan selama 5 hari dan diremaserasi selama 2 hari hingga diperoleh ekstrak kental sebanyak 87,86 gram. Rendemen yang diperoleh $21.96 \% \mathrm{~b} / \mathrm{v}$.

Pengujian stabilitas fisik terhadap Sediaan Gel Ekstrak Etanol Daun Kersen pada konsetrasi berbeda yaitu 5\%, 10\% dan $15 \%$. Pengujian ini meliputi uji organoleptik, uji homogenitas, uji pH,daya sebar, daya lekat, uji konsistensi dan cycling test. Pengujian fisik ini bertujuan untuk melihat stabilitas dan kelayakan suatu sediaan.

Pengujian organoleptik meliputi bentuk, warna dan bau. Hasil pengamatan menunjukkan bahwa semua formulasi gel yang dihasilkan berbentuk semipadat karakteristik dari gel pada umumnya, berwarna dan memiliki bau khas Tanaman Kersen. Semakin tinggi penambahan konsentrasi ekstrak daun Kersen, maka semakin kuat bau yang dihasilkan dan warna gel berubah. Hal ini tampak dari perubahan warna dari gel, semakin tinggi kadar konsetrasi yang terkandung, maka warna gel akan semakin cokelat. Begitu pula halnya dengan bau khas Tanaman Kersen yang tercium dari gel konsetrasi 5\%, 10\% dan $15 \%$. Semakin tinggi konsentrasi, maka semakin tercium bau khas Tanaman Kersen. Setelah dilakukan penyimpanan tidak terjadi perubahan warna, bentuk dan bau pada sediaan gel, ini dapat diartikan bahwa gel ekstrak daun Kersen memiliki stabilitas yang baik dalam penyimpanan karena tetap sama pada waktu sebelum penyimpanan dan sesudah penyimpanan.

Pengujian homogenitas bertujuan untuk melihat dan mengetahui tercampurnya bahan-bahan sediaan gel sehingga tidak terlihat adanya butiran-butiran kasar. Pengujian dilakukan terhadap gel ekstrak daun Kersen dengan konsentrasi 5\%, 10\% dan $15 \%$. Hasil pengujian dari ketiga formulasi sediaan sebelum dan sesudah penyimpanan menunjukkan susunan yang homogen (tidak adanya butiran kasar). Hal ini sesuai dengan persyaratan homogenitas gel yaitu gel harus menunjukkan susunan yang homogen serta tidak adanya butiran kasar pada gel (Kumasen et al, 2013).

Pengukuran $\mathrm{pH}$ pada gel ekstrak daun kersen untuk mengetahui kadar asam dan basa dari sediaan gel dan juga untuk melihat keamanan sediaan gel agar tidak mengiritasi kulit ketika diaplikasikan. Nilai $\mathrm{pH}$ untuk sediaan topikal harus sesuai dengan $\mathrm{pH}$ kulit yaitu 4,5-6,5. Pengujian $\mathrm{pH}$ pada sediaan gel menggunakan stik pH dengan mecelupkan stik pH meter kedalam gel yang telah dibuat. Hasil pengukuran $\mathrm{pH}$ gel dari masing-masing 
PHARMACON- PROGRAM STUDI FARMASI, FMIPA, UNIVERSITAS SAM RATULANGI,

Volume 8 Nomor 3 Agustus 2019

konsentrasi sebelum dan sesudah penyimpanan didapatkan nilai $\mathrm{pH}$ yang sama yaitu 5. $\mathrm{pH}$ gel ekstrak daun kersen ini menunjukkan $\mathrm{pH}$ yang sesuai dengan persyaratan $\mathrm{pH}$ gel, $\mathrm{pH}$ yang terlalu asam dapat memyebabkan iritasi pada kulit sedangkan untuk nilai $\mathrm{pH}$ yang terlalu basa dapat menyebabkan kulit bersisik. Nilai pH gel ini sesuai dengan $\mathrm{pH}$ kulit sehingga aman digunakan pada kulit yakni 4,5-6,5 (Tranggono dan Latifa, 2007).

Pengujian daya sebar merupakan pengujian yang dilakukan untuk mengetahui kemampuan penyebaran gel pada permukaan kulit dimana diharapkan gel mampu menyebar dengan mudah pada saat diaplikasikan pada telapak tangan. Hasil pengujian daya sebar untuk sediaan gel sebelum dilakukan penyimpanan konsentrasi $5 \% \quad 5,7 \mathrm{~cm}$, konsentrasi $10 \% 6 \mathrm{~cm}$ dan konsetrasi $15 \%$ yaitu $6,2 \mathrm{~cm}$. Hasil pengujian daya sebar gel setelah di lakukan penyimpanan untuk konsentrasi $5 \% 5,5 \mathrm{~cm}$, konsentrasi $10 \% \quad 5,7 \quad \mathrm{~cm}$ dan untuk konsentrasi 15\% 5,9 cm . Dari hasil uji daya sebar dengan menggunakan beban yang sama terlihat sedikit perubahan, diketahui semakin tinggi konsentrasi penambahan ekstrak gel maka semakin rendah daya sebar gel, karena semakin kental konsistensinya, maka semakin kecil daya sebar yang dihasilkan. Dari hasil yang didapat menunjukkan ketiga formulasi sediaan gel yang dihasilkan memenuhi syarat daya sebar yang baik yaitu 5-7 cm (Garg et al, 2002).

Hasil pengujian daya lekat sediaan gel daun kersen dilakukan untuk mengetahui kemampuan melekat gel pada permukaan kulit. Daya lekat gel yang baik adalah lebih dari 1 detik, semakin lama gel melekat pada kulit maka semakin banyak zat aktif yang diabsorbsi dan gel akan memberikan efek terapi yang lebih optimal dan semakin tinggi konsentrasi maka semakin banyak koloid yang terbentuk dan semakin tinggi pula daya lekatnya (Voight, 1984).

Pengujian konsistensi dilakukan untuk melihat apakah sediaan gel yang telah dibuat mengalami pemisahan fase setelah disentrifugasi dengan kecepatan 3800 rpm selama lima jam. Hasil pengujian sebelum dan sesudah penyimpanan menunjukkan bahwa semua sediaan gel tidak terlihat adanya pemisahan fase. Hal ini berarti sediaan gel yang dihasilkan tetap stabil dan tidak terpengaruh gaya gravitasi untuk penyimpanan selama setahun (Djajadisastra $e t$ al, 2009).

Metode yang digunakan untuk uji aktivitas antibakteri adalah difusi agar menggunakan sumuran dengan media Nutrien Agar (NA). Metode ini dilakukan untuk mengetahui besarnya diameter zona bening pada bakteri Staphylococcus aureus setelah inkubasi selama 24 jam. Daya hambat menurut Davis dan Stout (1971) terbagi atas : sangat kuat (zona hambat > $20 \mathrm{~mm}$ ), kuat (zona hambat 10-20 $\mathrm{mm}$ ), sedang (zona hambat 5-10 mm) dan lemah (zona hambat $<5 \mathrm{~mm}$ ). Pengujian aktivitas antibakteri ditentukan berdasarkan diameter zona hambat disekitar pencadang yang berisi larutan uji. Hasil pengujian yang dilakukan, gel ekstrak daun Kersen dengan konsentrasi $5 \%, 10 \%$ dan $15 \%$ menunjukan aktivitas antibakteri dengan adanya zona hambat disekitar sumuran. Diameter zona hambat disekitar sumuran diukur menggunakan jangka sorong dengan cara mengukur secara horizontal dan vertical kemudian hasil yang didapatkan dikurangi diameter sumuran 7 $\mathrm{mm}$. Gel ekstrak daun kersen konsentrasi 5\%, $10 \%$, dan $15 \%$ memberikan daya hambat yang dikategorikan kuat dengan zona hambat berturut-turut $10 \mathrm{~mm}, 11,66 \mathrm{~mm}$, dan $12 \mathrm{~mm}$. Kontrol positif memberikan daya hambat kuat dengan zona hambat $15 \mathrm{~mm}$ dan kontrol negatif tidak memberikan daya hambat karena menghasilkan zona hambat $0 \mathrm{~mm}$. Dari hasil 
PHARMACON- PROGRAM STUDI FARMASI, FMIPA, UNIVERSITAS SAM RATULANGI,

Volume 8 Nomor 3 Agustus 2019

tersebut dapat dilihat bahwa gel ekstrak daun Kersen dengan konsentrasi 5\%, 10\% dan 15\% dapat menghabat aktivitas bakteri staphylococcus aureus. Adanya zona hambat yang terbentuk karena adanya senyawa antibakteri pada daun kersen. senyawa flavonoid, saponin, triterpen, steroid, dan tannin (Kuntorini, 2011). Mekanisme kerja flavonoid sebagai antibakteri adalah membentuk senyawa kompleks dengan protein ekstraseluler dan terlarut sehingga dapat merusak membran sel bakteri dan diikuti dengan keluarnya senyawa intraseluler (IndoBIC, 2005 dalam Nuria et al, 2009). Sitoplasma dalam sel semua hidup dibatasi oleh membran sitoplasma, yang berperan sebagai barrier permeabilitas selektif fungsi transport aktif dan kemudian mengontrol komposisi internal sel. Jika fungsi integritas sel membrane sitoplasma dirusak, makromolekul dan ion keluar dari sel, kemudian sel rusak atau terjadi kematian (Brooks, 2004). Dari hasil yang didapat menunjukkan semakin tinggi konsentrasi sediaan gel maka semakin besar daya hambat yang dihasilkan.

Hasil pengujian antiseptik sediaan gel daun kersen pada konsentrasi 5\% memiliki koloni 20 koloni, konsentrasi $10 \%$ sebanyak 14 koloni, dan konsentrasi 15\% sebanyak 11 koloni. Pengujian pada handsanitizer Carex ${ }^{\circledR}$ (kontrol positif) rata-rata sebanyak 15 koloni dan pada basis gel (control negatif) menghasilkan rata-rata jumlah koloni sebanyak 27. Jumlah rata-rata penurunan koloni terjadi dengan semakin tinggi konsentrasi ekstrak daun kersen yang terdapat dalam formula gel antiseptic tangan. Pada konsentrasi $10 \%$ menghasilkan rata-rata penurunan jumlah koloni yang sifnifikan dibandingkan dengan gel konsentrasi 5\%. Sehingga dapat dilihat bahwa pada konsentras gel ektrak daun kersen telah memiliki efektivitas antiseptik dan diikuti dengan semakin tingginya konsentrasi gel 15\% yang mampu menekan dan menurunkan jumlah koloni. Sehingga konsentrasi gel 15\% merupakan gel dengan efektivitas antiseptik yang paling baik. Hal ini dikarenakan semakin tinggi konsentrasi maka semakin banyak eksrak yang digunakan dalam formulasi sehingga kandungan senyawa dalam sediaan semakin besar.

Analisis data dari hasil pengujian antiseptik dilakukan dengan pengujian statistic One Way Anova digunakan sebagai dasar pengambilan keputusan suatu hipotesis. Hipotesis dalam penelitian ini berupa $H_{0}$ yakni gel ekstrak daun kersen dengan konsentrasi 5\%, 10\%, dan $15 \%$ tidak memiliki efektivitas sebagai antiseptik tangan dan $H_{1}$ yakni gel ekstrak daun kersen dengan konsentrasi 5\%, 10\%, dan 15\% memiliki efektivitas sebagai antiseptik tangan. Pengambilan keputusan yang diterima dan hipotesis yang ditolak didasarkan pada perbandingan $\mathrm{F}$ hitung dan $\mathrm{F}$ tabel, dengan syarat jika $\mathrm{F}$ hitung kurang dari $\mathrm{F}$ tabel maka $H_{0}$ diterima, $H_{1}$ ditolak. Apabila $\mathrm{F}$ hitung lebih besar dari $\mathrm{F}$ tabel maka $H_{0}$ ditolak, $H_{1}$ diterima. Dari hasil uji One Way Anova berdasarkan data konsentrasi, control dan jumlah koloni diperoleh nilai $\mathrm{F}$ hitung 71,048 sig. 000. Untuk penentuan $\mathrm{F}$ tabel dengan menggunakan tingkat keyakinan 95\%, $\alpha=5 \%$, df1 jumlah variabel (perlakuan) dikurangkan $1(5-1=4)$ diperoleh nilai 4 dan df2 jumlah (N) dikurangi jumlah variabel $(15-5=10)$ diperoleh nilai 10. Dari data diperoleh F tabel bernilai 3,48 (tabel $\mathrm{F}$ dapat dilihat pada lampiran 21), sehingga $\mathrm{F}$ hitung lebih dari $\mathrm{F}$ tabel $(71,048>3,48)$. Berdasarkan analisis tersebut, dengan demikian hipotesis yang diterima ialah $H_{1}$ yakni gel ekstrak daun kersen dengan konsentrasi 5\%, 10\%, dan 15\% memiliki efektivitas sebagai antiseptik tangan. 


\section{KESIMPULAN}

Berdasarkan hasil penelitian dapat disimpulkan bahwa :

1. Ekstrak etanol daun Kersen dapat diformulasikan menjadi sediaan gel antiseptik tangan dengan konsentrasi 5\%, $10 \%$ dan $15 \%$ dan telah memenuhi syarat parameter uji yaitu pengujian organoleptik, homogenitas, $\mathrm{pH}$, daya sebar, konsistensi, daya lekat, antiseptik dan cycling test.

2. Sediaan gel ekstrak etanol daun kersen dapat memberikan efek antibakteri terhadap bakteri Staphylococcus aureus dengan diameter rata-ratanya pada konsentrasi $5 \% \quad 10,00 \mathrm{~mm}$, konsentrasi $10 \%$ 11,66 mm, konsentrasi 15\% 12,00 $\mathrm{mm}$ yang dikategorikan kuat.

\section{SARAN}

Perlu dilakukan modifikasi basis gel dalam formulasi untuk memperbaiki fisik sediaan serta penambahan bahan pengawet untuk memperluas spectrum antimiktroba sehingga dapat memperpanjang masa simpan sediaan.

\section{DAFTAR PUSTAKA}

Anonim, 2013. Badan Penelitian dan Pengembangan Kesehatan Departemen Kesehatan Republik Indonesia. Riset kesehatan dasar (RISKESDAS). Laporan nasional $2013: 2013$

Ansel, H. C. 1989. Pengantar Bentuk Sediaan Farmasi Edisi Keempat. UI Press,Jakarta

Brooks, G.F., Butel, J.S., Ornston, L.N. 2004. Mikrobiologi Kedokteran. Ed.20,
Alih Bahasa Edi Nugroho, R.F. Maulany, EGC. Jakarta

Davis, W. W., Stout, T. R. 1971. Disc Plate Methods of Microbiology. 22(4): 659-665

Dewi, R.K. 2010. Optimasi Formulasi Mikroemulsi Sediaan Hormon Testosteron Undekanoat [Skripsi]. Universitas Negeri Islam Negeri Syarif Hidayatullah,Jakarta.

Djajadisastra, J., Mun'im, A., Desi, N. P. 2009. Formulasi Gel Topikal dari Ekstrak Nerii folium dalam Sediaan Antijerawat. Jurnal Farmasi Indonesia. 4: 210-216.

Garg, A., Aggarwal, D., Garg, S., Sigla, A. K. 2002. Spreading of Semisolid Formulation: An Update. Pharmaceutical Technology. 84102.

Girou, Emmanuelle. 2002. Efficacy of handrubbing with alcohol based solution versus standard handwashing with antiseptic soap: randomized clinical trial. British Medical Journal, 325.

Hamzah, M., Mazwadeh. 2006. AntiInflammantory Activity of A Chillea and Ruscus Topikal Gel on Carrageenan-Induced Paw Edema in Rats. Acta Poloniae PharmaceuticalDrug Reseacrh. 63(4):277-280

Kristanti,A.N., Aminah.,M. Tanjung., B.,Kurniadi. 2008. Buku Ajar Fitokimia.Unair Press, Surabaya. 
PHARMACON- PROGRAM STUDI FARMASI, FMIPA, UNIVERSITAS SAM RATULANGI,

Volume 8 Nomor 3 Agustus 2019

Kumesan YAN., Yamlean PVY., Supriati. 2013. Formulasi dan Uji Aktivitas Antijerawat Ekstrak Umbi Bakung (Crinum Asiaticum L.) Terhadap Bakteri Staphylococcus aureus Secara In Vitro. Pharmacon. 2(2).

Kuntorini, E.M., Fitriana, S., Astuti, D.M. 2011. Stntktur Anatomi Dan Uji Aktivitas AntioksidanEkstrak Metanol Daun Kersen (Muntingia calabura). Universitas Lampung, Lampung.

Lindawati, E., Lestarie, N., Nurlaela, E., Rival, M.A., Maryati, S. 2014. Inovasi "Kewangi" Sebagai Gel Antiseptik Alami dari Minyak Atsiri Kemangi (Ocimum canum). Laporan Akhir Pekan Kreativitas Mahasiswa. IPB. Bogor.

Maswadeh, H., Semreen, M., Naddaf, A. 2006. Anti-inflammatory Activity of Achillea and Ruscus Topical Gel On Carragenan-induced Paw Edema in Rats. Acth Poloniae Pharmaceutica Drug Research.63(4).

Nuria, Maulia Cut., A. Faizatun., Sumantri. 2009. Uji Aktivitas Antibakteri Ekstrak Etanol Daun Jarak Pagar (Jatropha curcas L) terhadap Bakteri Staphylococcus aureus ATCC 25923, Escherichia coli ATCC 25922, dan Salmonella typhi ATCC 1408. Mediagro.

5:(2):26- 37.

Retno, S., Isadiartuti, D. 2005. Uji efektifitas sediaan gel antiseptic tangan yang mengandung etanol dan triklosan. Majalah Farmasi Airlangga, Surabaya.

Swastika NSP, alissya, Mufrod, Purwanto.2013. Aktivitas Antioksidan Krim Ekstrak Sari Tomat (Solanum lycopersicum L.). Medical Journal. 18(3): 132-140.

Tranggono, Retno, I., Latifah., Fatimah. 2007. Buku Pegangan Ilmu Pengetahuan Kosmestik. PT. Gamedia Pustaka Utama,Jakarta.

Voigth, R. 1995.Buku Pelajaran Teknologi Farmasi. Edisi ke-5. Gajah Mada University Press, Yogyakarta. 